\title{
PENGARUH DESAIN COURTYARD TERHADAP KONSUMSI ENERGI UNTUK AC (AIR CONDITIONER) DAN PENCAHAYAAN Studi Simulasi Hipotetik Bangunan Tinggi Perkantoran di Jakarta
}

\author{
Galih Gusti Yudha Saelendra1, Jatmiko Adi Suryabrata, ${ }^{2}$ Dimas Wihardyanto ${ }^{3}$ \\ ${ }^{1}$ Program S2 Arsitektur, Fakultas Teknik, Universitas Gadjah Mada \\ 2, 3 Jurusan Teknik Arsitektur dan Perencanaan, Fakultas Teknik, Universitas Gadjah Mada \\ Email : galihsaelendra@gmail.com
}

\begin{abstract}
Increasing the natural lighting can reduce the lighting energy consumption haw a weather but it can be potentially increasing the weather energy so there must be strategy needed to save the energy. That condition is the problem statement of this research, to know the configuration of the natural lighting and the effective cooling load. In this research, the simulation method with hypothetic building object has been used to test how big the influence of courtyard dimension, (Wall To Window Ratio) WWR and glass type towards the total consumption of energy for AC (Air Conditioner) and lighting. The result of this research is the most affective courtyard configuration is courtyard dimension 1, WWR $30 \%$, stopsol glass type. From the courtyard dimension variable, WWR and glass type, for the total energy consumption for $A C$ and the highest lighting influenced its energy efficiency is clear glass type 15,56\%, panashap glass 9,09\%, WWR 70\% 6,25\%, WWR 50\% 1,91\%, courtyard dimension 2 0,27\%, courtyard dimension $30,18 \%$. In Jakarta with the tropical climate is not suitable to apply the courtyard application which is too big, it must be concerned the wide and high proposition so the total energy consumption for AC and lighting would not be so big. While the open orientation is not so influencing the sun radiation, so avoid the open part from east and west. For the WWR building range is between 50\% - 70\% must be paid attention in choosing the glass type because as small as the SC (Shading Coefficient) is lower the sun radiation.
\end{abstract}

Keywords : AC (Air Conditioner), Courtyard, Glass type, Lighting, WWR.

\begin{abstract}
ABSTRAK
Meningkatkan pencahayaan alami dapat mengurangi konsumsi energi pencahayaan namun, berpotensi meningkatkan energi penghawaan maka diperlukan strategi untuk penghematan energi. Kondisi tersebut yang menjadi permasalahan dalam kajian ini, untuk mengetahui konfigurasi pencahayaan alami dan beban pendinginan yang efektif. Dalam kajian ini digunakan metode simulasi dengan objek bangunan hipotetik untuk menguji besar pengaruh dimensi courtyard, (Wall To Window Ratio) WWR dan Jenis kaca terhadap total konsumsi energi untuk AC (air conditioner) dan pencahayaan. Hasil dari kajian ini adalah konfigurasi courtyard yang paling efektif yaitu dimensi courtyard 1, WWR 30\%, jenis kaca stopsol. Dari variabel dimensi courtyard, WWR dan jenis kaca, untuk total konsumsi energi untuk AC dan pencahayaan yang paling tinggi berpengaruh dalam efesiensi energinya adalah jenis kaca clear $15.56 \%$, kaca panashap $9.09 \%$, WWR 70\% 6,25\%, WWR 50\% $1,91 \%$, dimensi courtyard $20.27 \%$, dimensi courtyard $30.18 \%$. Pada kota Jakarta dengan kondisi iklim tropis kurang cocok untuk pengaplikasian courtyard yang terlalu besar, harus di perhatikan proporsi lebar dan tinggi courtyard agar total konsumsi energi untuk AC dan pencahayaan tidak terlalu besar. Sedangkan orientasi bukaan sangat berpengaruh terhadap radiasi matahari, sehingga hindari bukaan dari arah timur dan barat. Untuk range WWR bangunan antara $50-70 \%$ perlu di perhatikan dalam memilih jenis kaca karena semakin kecil SC (Shading Coefficient) maka semakin rendah radiasi matahari.
\end{abstract}

Kata kunci: AC (Air Conditioner), Courtyard, Jenis kaca, Pencahayaan, WWR.

\section{PENDAHULUAN}

Joko (2009) berpendapat kebutuhan energi di Indonesia dari tahun ke tahun meningkat secara eksponensial. Diperkirakan pada tahun 2035 meningkat hampir empat kali lipat dari kebutuhan energi di tahun 2010. Kira-kira $24 \%$ dari total energi digunakan oleh bangunan, dan 48,9\% dari energi pada bagunan di gunakan untuk system 
HVAC. Sedangkan menurut Buku Panduan Pengguna Bangunan Gedung Hijau Jakarta sebagian besar energi pada bangunan di Indonesia digunakan oleh sistem HVAC terlepas dari tipe bangunannya. HVAC berkontribusi sekitar $47 \%$ - $65 \%$ dari total konsumsi energi bangunan. Gabungan pencahayaan buatan dan beban steker berkontribusi sebesar $15 \%-25 \%$ dari total konsumsi energi. Oleh karena itu,dengan mengurangi konsumsi energi untuk HVAC dan pencahayaan buatanmelalui desain pasif dan aktif akan mengurangi konsumsi energi bangunan keseluruhan secara signifikan. Menurut buku Panduan Pengguna Bangunan Gedung Hijau Jakarta sebagian besar energi pada bangunan di Indonesia digunakan oleh sistem HVAC terlepas dari tipe bangunannya.

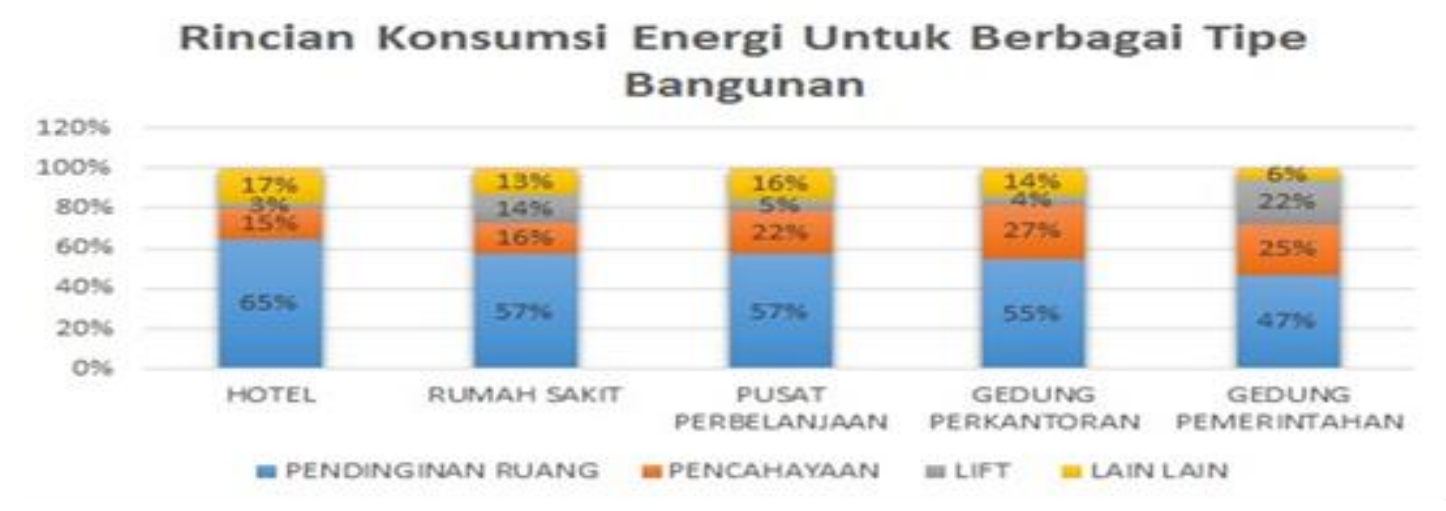

Gambar 1 Rincian Konsumsi Energi untuk Berbagai Tipe Bangunan

(Sumber : Panduan Pengguna Bangunan Gedung Hijau Jakarta Vol. 1 Selubung Bangunan Berdasarkan Peraturan Gubernur No. 38/2012)

Indonesia yang terletak pada garis khatulistiwa dengan iklim tropis menerima cahaya siang hari yang sangat cukup dan tersedia sepanjang tahun tetapi banyak hasil rancangan arsitektur bangunan yang masih tergantung pada penggunaan listrik pada siang hari khususnya untuk pencahayaan ruangan. Akan tetapi, meningkatkan pencahayaan alami utuk mengurangi konsumsi energi pencahayaan namun, berpotensi meningkatkan energi penghawaan karena perolehan panas bangunan akan meningkat. Kondisi ini yang menjadi permasalahan dalam kajian ini untuk mengetahui konfigurasi pencahayaan alami dan beban pendinginan yang efektif.

Sharif, Zain, dan Surat (2010) berpendapat, penggunaan courtyard yang sebagai pengendali termal bioklimatik pada lingkungan terbangun cukup efisien. Courtyard adalah cara yang efektif untuk menciptakan lingkungan internal yang dapat melawan kondisi iklim tropis kering. Bekleyen dan Dalkiliç (2011) juga berpendapat bahwa courtyard adalah strategi sederhana untuk melindungi dari panas, digunakan untuk melarikan panas ekstrim keluar. Bagaimana dengan penerapan courtyard di indonesia dengan kondisi iklim tropis lembabnya apakah ada pengaruh atau tidak?.

Selain penerapan Courtyard, pengendalian termal umumnya di lakukan dengan pendinginan. Beban pendinginan dipengaruhi beberapa faktor diantaranya adalah beban yang berasal dari luar mesin pendingin dan beban yang berasal dari dalam ruangan. Maka perlu dilakukan kajian untuk mengkaji efektivitas courtyard trerhadap pengendalian termal kaitanya dengan "konsumsi energi untuk AC dan pencahayaan bangunan tinggi perkantoran 
di jakarta dengan memperhitungkan dimensi courtyard, wwr dan jenis kaca".

Dalam kajian ini terdapat lingkup dan batasan kajian, antara lain:

1. Lokasi bangunan yang diteliti diasumsikan berada di Jakarta

2. Konfigurasi bangunan yg di teliti dibatasi oleh variable WWR, jenis material kaca, Reflektansi dinding luar, bentuk dan konfigurasi courtyard.

3. Kajian dibatasi menggunakan bangunan hipotetik berlantai banyak (10 lantai) berbentuk kotak dengan layout persegi dan persegi panjang.

4. Tipikal bangunan yang diteliti adalah gedung perkantoran dan beroperasi mulai pukul 08.00 hingga 17.00 .

5. Simulasi dilakukan tanpa memperhitungkan pengaruh pembayangan bangunan lain yang berada di sekitar bangunan hipotetik.

6. Untuk penerangan ruangannya di setting 300 lux sesuai standart pencahayaan perkantoran.

\section{METODE}

Kajian ini menggunakan simulasi model sebagai obyek kajian. Model di bangun melalui kajian pustaka maupun simulasi awal untuk menentukan batasan bagi variabel yang diuji. Kajian simulasi berguna ketika berkaitan dengan permasalahan skala dan kompleksitas.

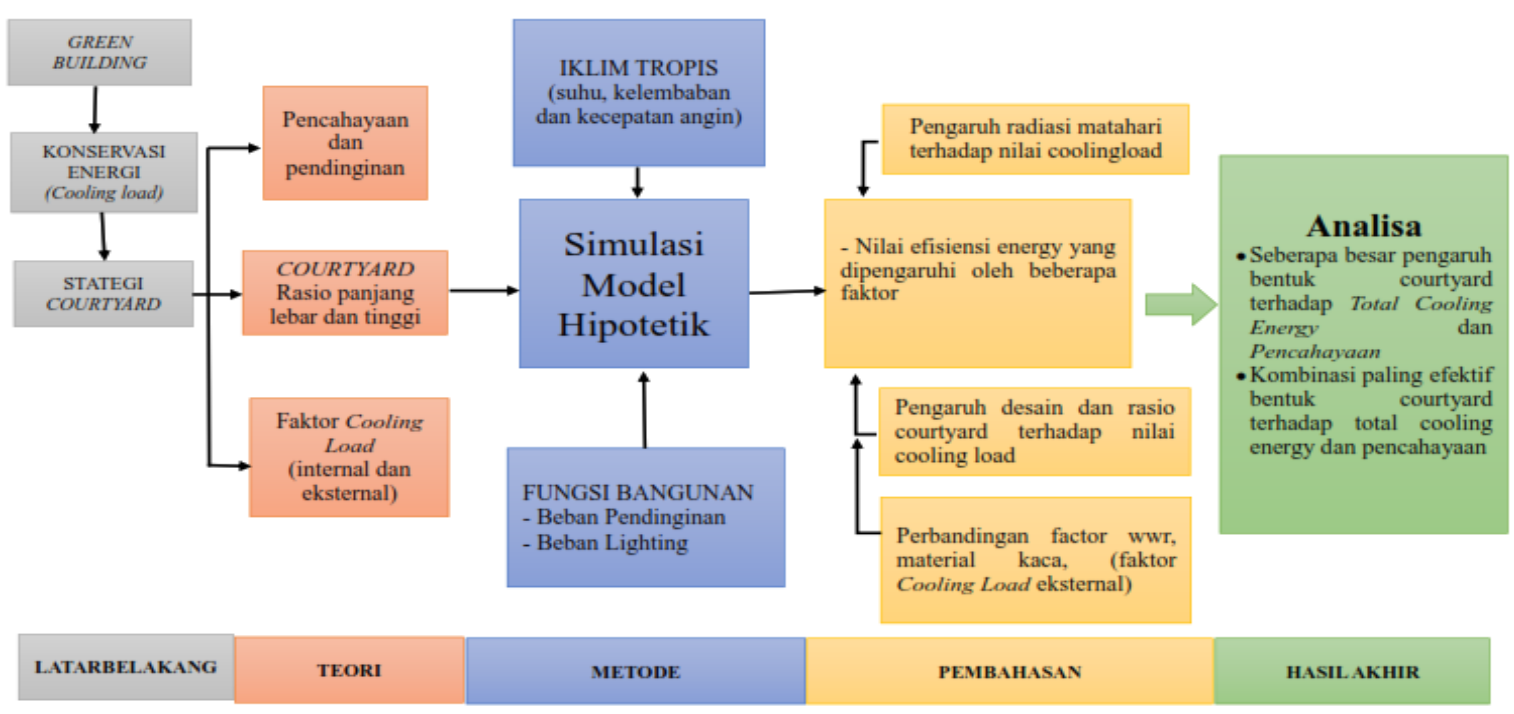

Gambar 2. Kerangka pikir

(sumber : dokumen pribadi)

Dalam kajian ini variabel independe antara lain sebagai berikut:

\section{WWR (window to wall ratio)}

Proporsi luas jendela memiliki pengaruh sangat besar terhadap beban pendinginan karena menentukan total perolehan panas yang masuk kedalam bangunan. Hal ini dikarenakan jendela kaca dapat memasukkan panas kedalam bangunan jauh lebih tinggi dibandingkan dengan dinding masif. Oleh karena itu rasio luas jendela terhadap dinding (wwr) yang lebih tinggi biasanya menyebabkan beban pendinginan lebih tinggi. Mengurangi luas 
jendela adalah salah satu solusi paling efektif untuk mengurangi beban pendinginan dan konsumsi energi bangunan secara keseluruhan.

Panduan Pengguna Bangunan Gedung Hijau Jakarta berdasarkan Peraturan Gubernur No. 38/2012 wwr untuk perkatoran, retai dan rumah sakit antara $30 \%$ sampai $70 \%$. Standar global menetapkan batas maksimum dari rasio bidang jendela ke dinding (window to wall ratio (wwr)) antara $25 \%$ dan $50 \%$. Intensitas konsumsi energi pada ruang berbanding lurus dengan WWR. Semakin besar nilai wwr, maka tingkat konsumsi energi pada ruang tersebut juga akan semakin besar (Athoillah, 2014). Dalam kajian ini untuk WWR diasumsikan 30\%, $50 \%$, dan $70 \%$.

\section{Jenis Kaca}

Berdasarkan sifat termalnya, jenis kaca memiliki berbagai karateristik yang berbeda, tergantung dari sifat transmisi radiasi matahari (solar transmittance), daya serap radiasi matahari (solar absorptance), daya pantulan radiasi matahari (solar reflectance) dan transmisi cahaya (visible transmittance).

Dalam kajian ini kaca yang akan digunakan adalah kaca yang biasa di pakai secara umum adalah sebagai berikut :

Tabel 1 Daftar Jenis Kaca

\begin{tabular}{lcccccc}
\hline Jenis Kaca & Thickness & Transmitance & Reflectance & $\begin{array}{c}\mathbf{U} \\
\text { Factor } \\
\mathbf{W} / \mathbf{m}^{2}-\mathbf{k}\end{array}$ & SC & SHGC \\
\hline $\begin{array}{l}\text { Indoflot Clear } \\
8.0(1226)\end{array}$ & 7.8 & 0.702 & 0.866 & 5.746 & 0.890 & 0.774 \\
\hline $\begin{array}{l}\text { Panasap Euro } \\
\text { Gray 8.0 } \\
\text { (1233) }\end{array}$ & 7.9 & 0.361 & 0.340 & 5.748 & 0.630 & 0.548 \\
\hline $\begin{array}{l}\text { Stopsol } \\
\begin{array}{l}\text { Classic Green } \\
(4247)\end{array}\end{array}$ & 7.9 & 0.172 & 0.285 & 5.736 & 0.400 & 0.348 \\
\hline
\end{tabular}

\section{Dimensi Courtyard}

Dalam kajian ini model bangunan terdapat 3 model yang masing masing memiliki ukuran yang berbeda namun tinggi bangunan sama 40 meter (10 lantai). Lebar ruangan juga sama 4,5 $\mathrm{M}$ dengan asumsi efek radiasi yang masuk keruangan sama yaitu di hitung per $\mathrm{m}^{2}$.

Dimensi courtyard 1 untuk sisi utara, barat, selatan dan timur ukuran bangunannya 40 $M$ sedangkan untuk dimensi courtyard sisi utara, barat, selatan dan timur sama yaitu 22 M. Dimensi courtyard 2 sisi utara dan selatan panjang bangunanya $40 \mathrm{M}$ sedangkan sisi timur dan barat $62 \mathrm{M}$. Dimensi courtyard sisi utara dan selatan panjangnya $22 \mathrm{M}$ sedangkan sisi timur dan barat $44 \mathrm{M}$. Dimensi courtyard 3 sisi utara dan selatan panjang bangunanya $62 \mathrm{M}$ sedangkan sisi timur dan barat $40 \mathrm{M}$. Dimensi courtyard sisi utara dan selatan panjangnya $44 \mathrm{M}$ sedangkan sisi timur dan barat $22 \mathrm{M}$. 


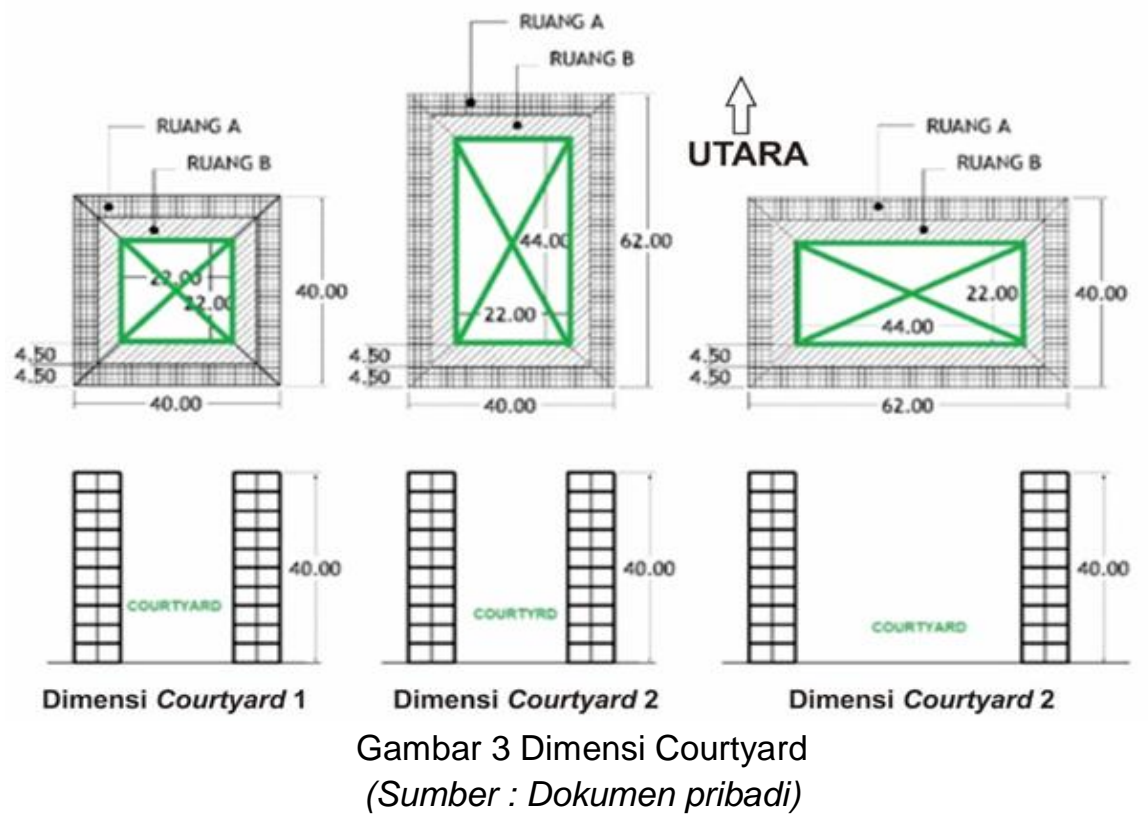

Dalam analisis kajian ini melalui beberapa tahapan. Dimulai dari pekerjaan persiapan, kemudian dilanjutkan dengan proses mengidentifikasi kebutuhan data, mengidentifikasi masalah, serta menyiapkan studi pustaka yang akan dipakai. Apabila data telah mencukupi kemudian dilanjutkan dengan proses analisa serta pembahasan akan data tersebut. Hasil dari analisa di atas menghasilkan beberapa solusi yang sekiranya dapat dipakai guna mengatasi permasalahan yang terjadi. Barulah kemudian diambil kesimpulan dan dipilih metode yang terbaik untuk penyelesaiannya.

Pada tahap Persiapan ini meliputi kegiatankegiatan survey pendahuluan ke lokasi untuk mendapatkan gambaran umum kondisi lapangan, Pendataan instansi yang terkait dengan sumber data, penyelesaian persyaratan administrasi untuk mendapatkan data dan melakukan studi pustaka sebagai bahan referensi dan acuan dalam penyusunan proposal kajian.

Rancangan kajian mengatur sistematika yang akan dilaksanakan dalam kajian. Memasuki langkah ini peneliti harus memahami berbagai metode dan teknik kajian. Metode dan teknik kajian disusun menjadi rancangan kajian. Mutu keluaran kajian ditentukan oleh ketepatan rancangan kajian serta pemahaman dalam penyusunan teori.

Sebelum melakukan kajian, bagaimana sejauh mungkin sudah menyiapkan segala alat dan perlengkapan kajian yang diperlukan sebelum terjun ke dalam kancah kajian. Dalam kajian ini memerlukan beberapa perlengkapan diantaranya adalah komputer atau laptop, Software EnergyPlus, dan Software sketchup.

Pada tahap ini merupakan kegiatan simulasi dan analisa hasil simulasi. Simulasi dilakukan bertingkat sesuai dengan hasil yang diharapkan.

Dalam simulasi ini dilakukan menggunakan model bangunan hipotetik dengan kondisi pengaplikasian courtyard pada tengahtengah bangunan konfigurasi dimensi Courtyard, WWR dan jenis kaca. Data hasil simulasi diolah dengan cara ditabelkan sesuai dengan variabelnya. Hasil dari simulasi ini akan dilihat nilai konsumsi

INERSIA, Vol. XIV No. 1, Mei 2018 
energi untuk AC $\left(\mathrm{Kwh} / \mathrm{m}^{2}\right)$ dan Beban pencahayaan $\left(\mathrm{Kwh} / \mathrm{m}^{2}\right)$. Untuk input data pada sofware energyplus adalah sebagai berikut :
1. Lokasi
Jakarta,
2. Reflektansi ground : indonesia
3. Reflektansi dinding : 0,2 dalam
0,5
4. Reflektansi plafond
0,7
6. Reflektansi dinding : 0,4 luar
0,4
0,6
7. Dayighting contro$$
300 \text { lux }
$$$$
\text { Lampu TL }
$$
9. Waktu operasional
08:00 - 17:00
10.Penggunan/orang
11. Jenis AC
WIB
12. Suhu pendingin $(A C)$
13. Kelembaban udara
14.Peralatan elektronik lainya

Berdasarkan hasil analisa simulasi awal kombinasi variabel bebasnya (Dimensi Courtyard, WWR dan jenis kaca) di ganti sesuai dengan yang sudah di tetapkan. Dari hasil simulasi ini akan di tabelkan dan di olah datanya sehingga mengetahui seberapa tinggat efektifitasnya terhadap total konsumsi energi untuk $A C$ dan pencahayaan.

\section{Tahap Akhir}

Tahap akhir kegiatan kajian ini adalah tahap penulisan laporan. Keseluruhan proses kajian dari awal hingga akhir, dan hasil dari analisa pada tahap pertengahan disajikan dalam bentuk laporan yang sistematis. Hasil dari tahap ini adalah laporan kajian.

\section{HASIL DAN PEMBAHASAN}

Dalam hal ini membahas tentang besarnya output total konsumsi energi untuk $A C$ dan pencahayaan terhadap variabel dimensi courtyard, WWR dan jenis kaca. Perbandingan total konsumsi energi untuk $A C$ dan pencahayaan dapat di gunakan sebagai parameter dalam mengukur efektifitas terhadap pengendalian termal.

Model bangunan terdapat 3 dimensi courtyard, 3 WWR dan 3 jenis kaca. Sehingga dalam simulasi ini diketahui konfigurasi courtyard yang paling efektif adalah sebagai berikut:

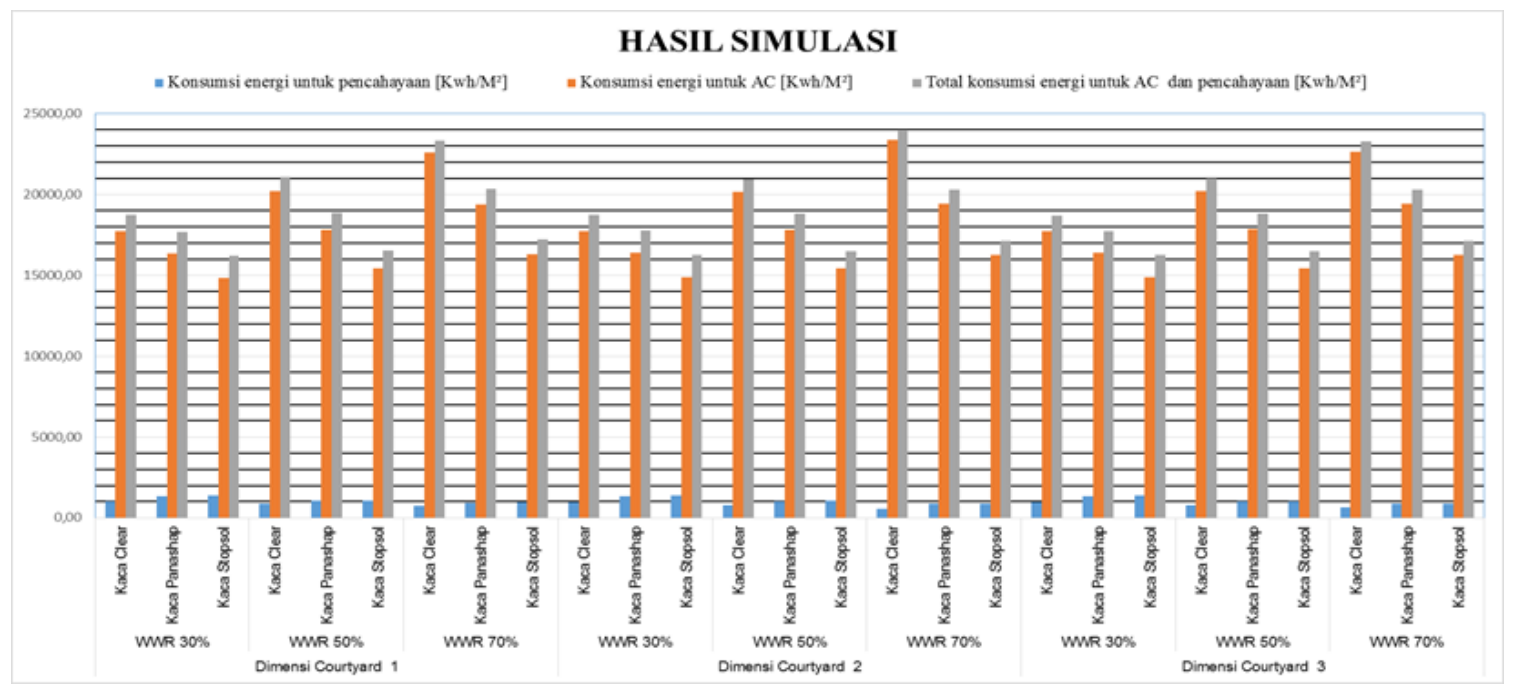

Gambar 4. Grafik Hasil Simulasi Berdasarkan Perbandingan Konfigurasi Courtyard 
Dari gambar 4 di atas menunjukan bahwa model courtyard 1, WWR 30\%, kaca stopsol untuk total konsumsi energi untuk AC dan pencahayaan. Pada konsumsi energi untuk $A C$ dan pencahayaan tertinggi adalah bentuk courtyard model 2, WWR $70 \%$ dan jenis kaca clear. Sedangkan konsumsi energi pencahayaan paling rendah di antara bentuk courtyard lainya adalah model 2, WWR $70 \%$ dan jenis kaca clear.

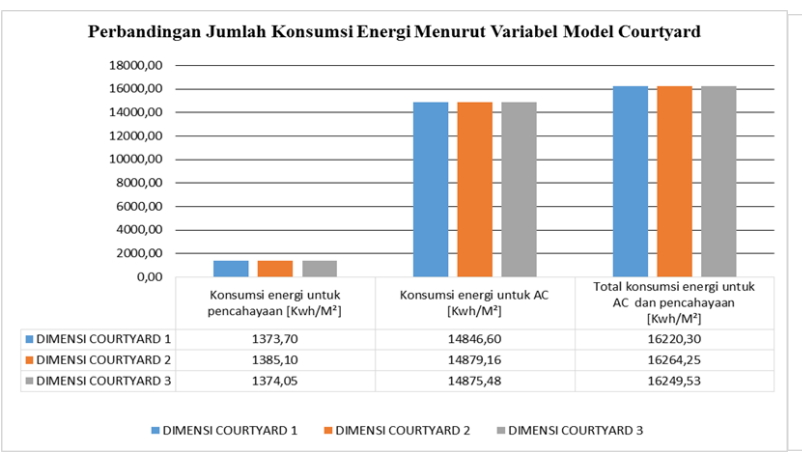

Maka model courtyard 1, WWR 30\%, kaca stopsol di jadikan acuan (base case) sebagai pembanding untuk bentuk courtyard yang lainya. Dalam hasil simulasi ini konfigurasi courtyardnya adalah base case (wwr 30\%, jenis kaca stopsol). Sedangkan dimensi courtyardnya digantiganti sesuai dengan variabel yang sudah di tentukan.

Gambar 5 Grafik Perbandingan Nilai Konsumsi Energi menurut Variabel Model Courtyard

Dari gambar 5 di atas menunjukan bahwa konsumsi energi pencahayaan courtyard 1 dibandingkan model courtyard 2 hanya meningkat $0.83 \%$. Sedangkan model courtyard 1 dibandingkan model courtyard 3 meningkat $0.03 \%$. Pada konsumsi energi untuk AC model courtyard 1 dibandingkan model courtyard 2 meningkat $0.22 \%$.

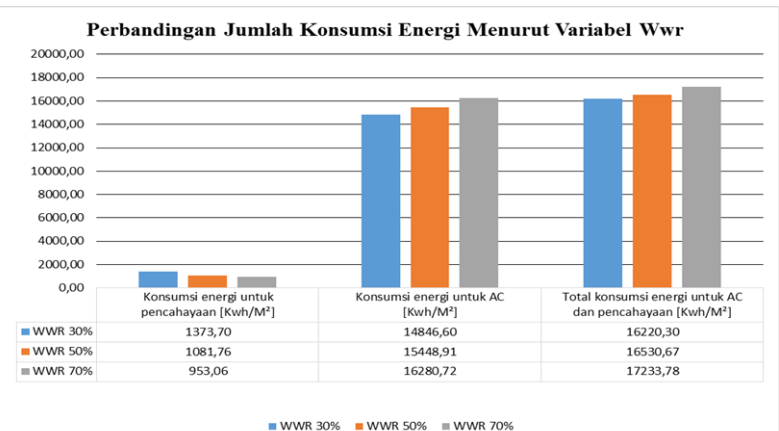

Sedangkan model courtyard 1 dibandingkan model courtyard 3 meningkat $0.19 \%$. Sedangkan total konsumsi energi untuk AC dan pencahayaan model courtyard 1 dibandingkan model courtyard 2 meningkat $0.27 \%$. Sedangkan model courtyard 1 dibandingkan model courtyard 3 meningkat $0.18 \%$.

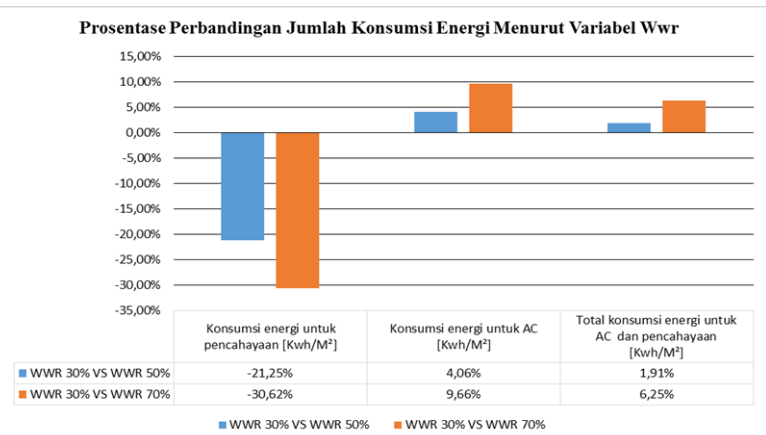

Gambar 6 Grafik Perbandingan Nilai Konsumsi Energi menurut Variabel WWR

Dari gambar 6 di atas menunjukan bahwa konsumsi energi pencahayaan WWR 30\% dibandingkan WWR 50\% menurun $21.25 \%$. Sedangkan WWR $30 \%$ dibandingkan WWR $70 \%$ menurun $30.62 \%$. Pada konsumsi energi untuk AC WWR 30\% dibandingkan WWR 50\% meningkat 4.06\%. Sedangkan WWR 30\% dibandingkan WWR 70\% meningkat $9.66 \%$. Sedangkan total konsumsi energi 
untuk AC dan pencahayaan WWR 30\% dibandingkan WWR $50 \%$ meningkat $1.91 \%$. Sedangkan WWR $30 \%$

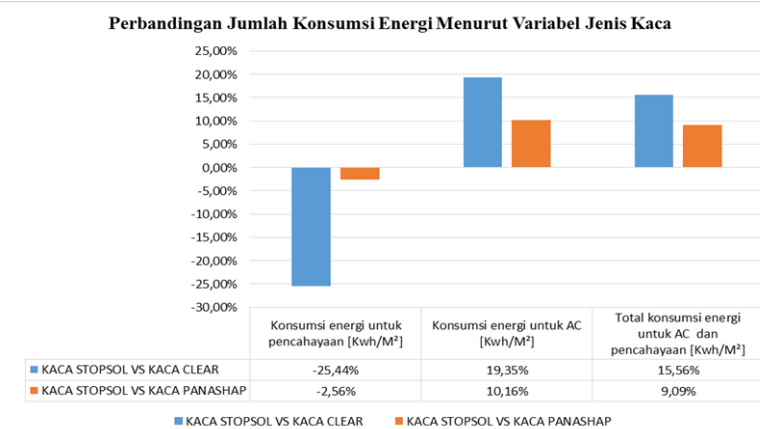

dibandingkan WWR 70\% meningkat $6.25 \%$.

Gambar 7. Grafik Perbandingan Nilai Konsumsi Energi menurut Variabel Jenis Kaca

Dari gambar 6 di atas menunjukan bahwa kaca stopsol dibandingkan jenis kaca clear konsumsi energi pencahayaan jenis pada jenis kaca clear menurun $25.44 \%$. Sedangkan jenis kaca stopsol dibandingkan jenis kaca panashap menurun $2.56 \%$. Pada jenis kaca stopsol dibandingkan jenis kaca clear konsumsi energi untuk $A C$ jenis kaca clear meningkat 19.35. Sedangkan jenis kaca stopsol dibandingkan jenis kaca panashap meningkat $6.09 \%$. Sedangkan total konsumsi energi untuk AC dan pencahayaan jenis kaca stopsol dibandingkan jenis kaca clear meningkat $15.56 \%$. Sedangkan jenis kaca stopsol dibandingkan jenis kaca panashap meningkat $10.16 \%$.
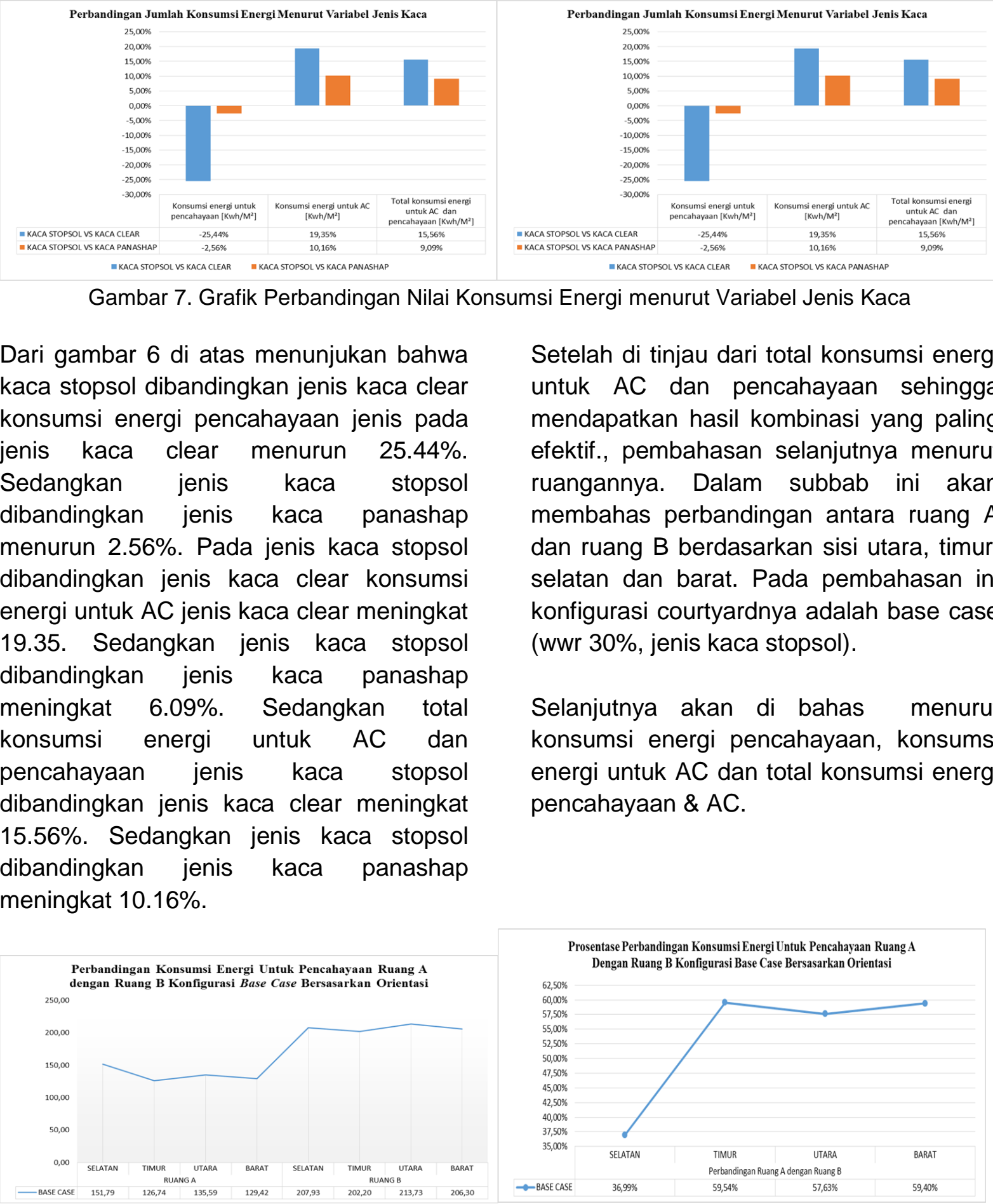

Gambar 8. Perbandingan Konsumsi Energi Pencahayaan Total Ruang A dan Ruang B setiap Sisinya

Pada gambar 8 perbandingan konsumsi energi untuk pencahayaan ketika konfigurasi base case sisi selatan, timur, utara maupun barat antara ruang $A$ dengan
Setelah di tinjau dari total konsumsi energi untuk AC dan pencahayaan sehingga mendapatkan hasil kombinasi yang paling efektif., pembahasan selanjutnya menurut ruangannya. Dalam subbab ini akan membahas perbandingan antara ruang $A$ dan ruang $B$ berdasarkan sisi utara, timur, selatan dan barat. Pada pembahasan ini konfigurasi courtyardnya adalah base case (wwr 30\%, jenis kaca stopsol).

Selanjutnya akan di bahas menurut konsumsi energi pencahayaan, konsumsi energi untuk $A C$ dan total konsumsi energi pencahayaan \& AC. 
Sedangkan prosentase perbandingan konsumsi energi untuk pencahayaan untuk base case antara ruang $A$ dengan ruang $B$ adalah sisi selatan naik $36.99 \%$, sisi timur $59.54 \%$, sisi utara $57.63 \%$ dan sisi barat
$59.40 \%$. Untuk hasil dari dimensi courtyard 2, dimensi courtyard 3, wwr 50\%, wwr $70 \%$, jenis kaca clear, jenis kaca panashap ada di halaman lampiran.
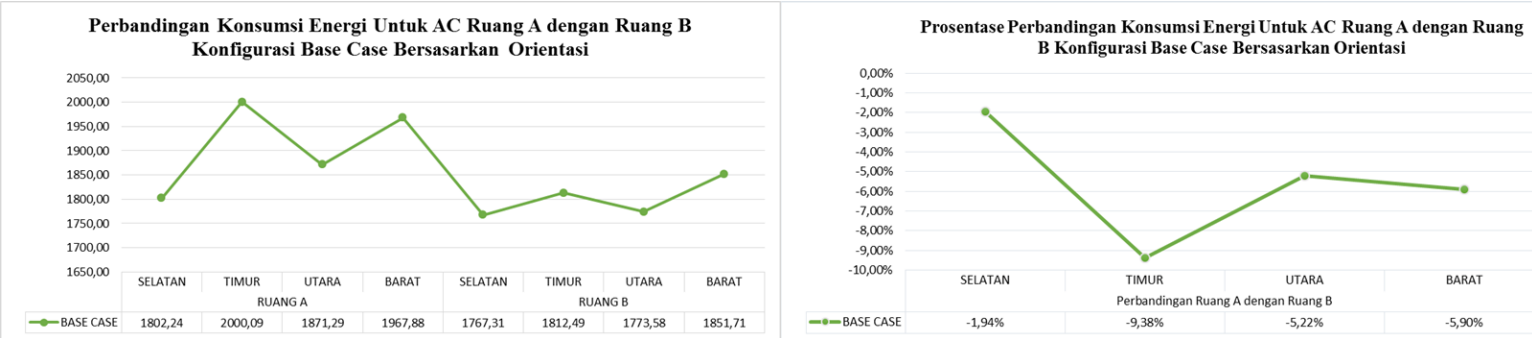

Gambar 9. Perbandingan Konsumsi Energi AC Total Ruang A dan Ruang B setiap Sisinya

Pada gambar 9 perbandingan konsumsi konsumsi energi untuk AC ketika konfigurasi base case sisi selatan, timur, utara maupun barat antara ruang $A$ dengan ruang $B$ sangat berbeda. Ruang $A$ membutuhkan konsumsi konsumsi energi untuk $A C$ yang lebih tinggi di bandingkan ruang $B$.
Sedangkan prosentase perbandingan konsumsi Konsumsi energi untuk $A C$ untuk base case antara ruang $A$ dengan ruang $B$ adalah sisi selatan turun $1.94 \%$, sisi timur $9.38 \%$, sisi utara $5.22 \%$ dan sisi barat $5.90 \%$.
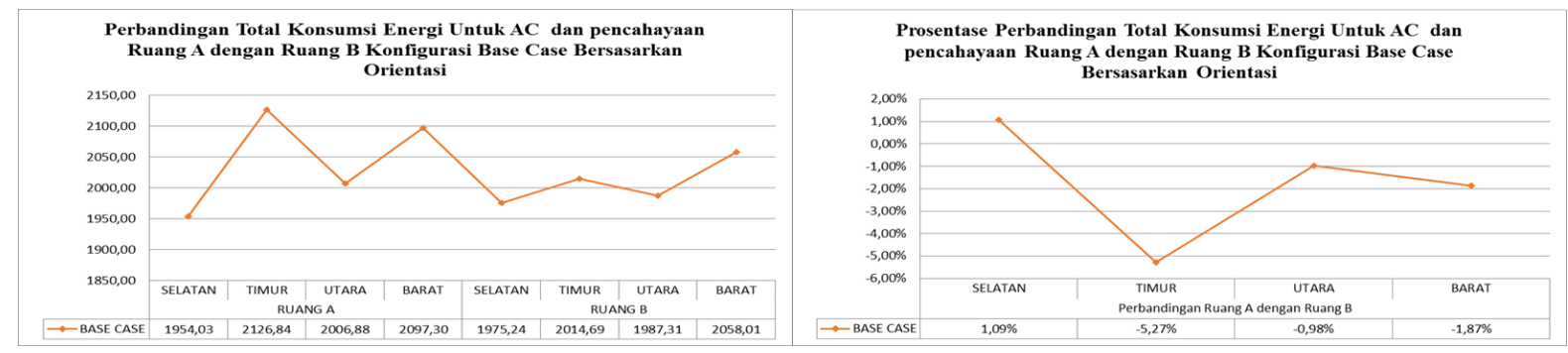

Gambar 10. Perbandingan Konsumsi Energi AC \& pencahayaan Total Ruang A dan Ruang B setiap Sisinya

Pada gambar 10 perbandingan total konsumsi energi untuk AC dan pencahayaan pada konfigurasi base case untuk sisi selatan lebih tinggi ruang $B$, sisi timu lebih tinggi ruang $A$, utara lebih tinggi ruang $A$ dan barat lebih tinggi ruang $A$.

Sedangkan prosentase perbandingan konsumsi total konsumsi energi untuk AC dan pencahayaan untuk base case antara ruang $A$ dengan ruang $B$ adalah sisi selatan naik $1.09 \%$, sisi timur, utara dan barat turun $5.27 \%$, 0.98\%, dan $1.87 \%$.

Setelah di tinjau dari hasil perbandingan ruang $A$ dan ruang $B$ terkait total konsumsi energi untuk $A C$ dan pencahayaan, ruang A pada batasan kajian tidak ada pengaruh pembayangan pada bangunan sekitar, maka pembahasan ini di fokuskan pada ruangan $B$ yang karena adanya pembayangan lantai gedung dari seberangnya. 
Pengaruh Desain Courtyard ... (Galih hal. 36-47)

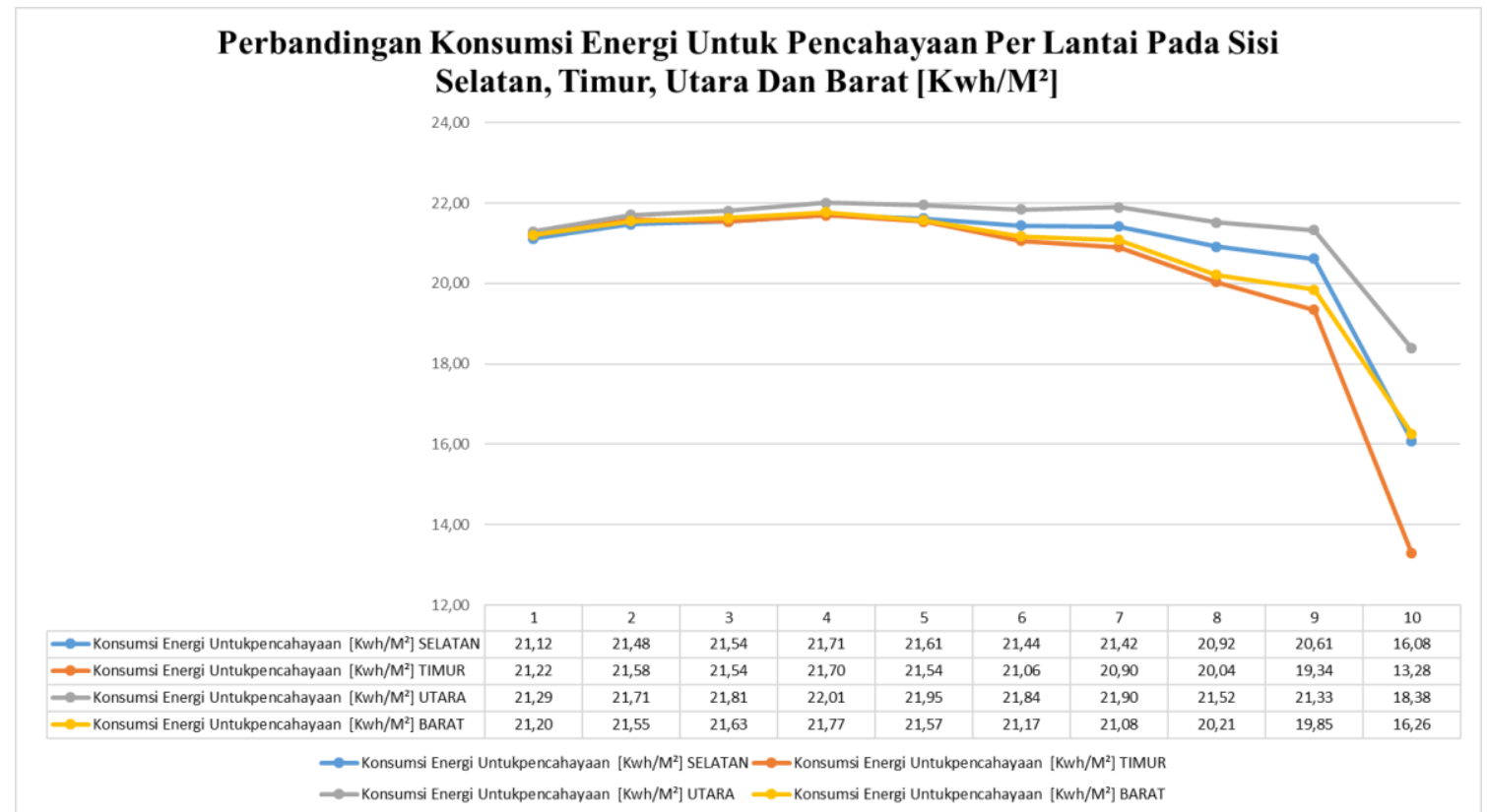

Gambar 11. Perbandingan Konsumsi Pencahayaan per Lantai pada Sisi Selatan, Timur, Utara dan Barat.

Pada gambar 11 di atas data yang di pakai dalam simulasi ini adalah data paling efisien dari total simulasi yang dilakukan dengan kombinsai courtyard model 1 , wwr $30 \%$, kaca stopsol sehingga mengasilkan data berikut.
Lantai 1 lebih rendah di bandingkan lantai 2 dan lantai 3. Pada lantai 4 turun lebih rendah dari lantai 3, lantai 5 naik dari lantai 4. Namun, lantai 6 sampai lantai 10 turun. Dan pada lantai 10 turun drastis.

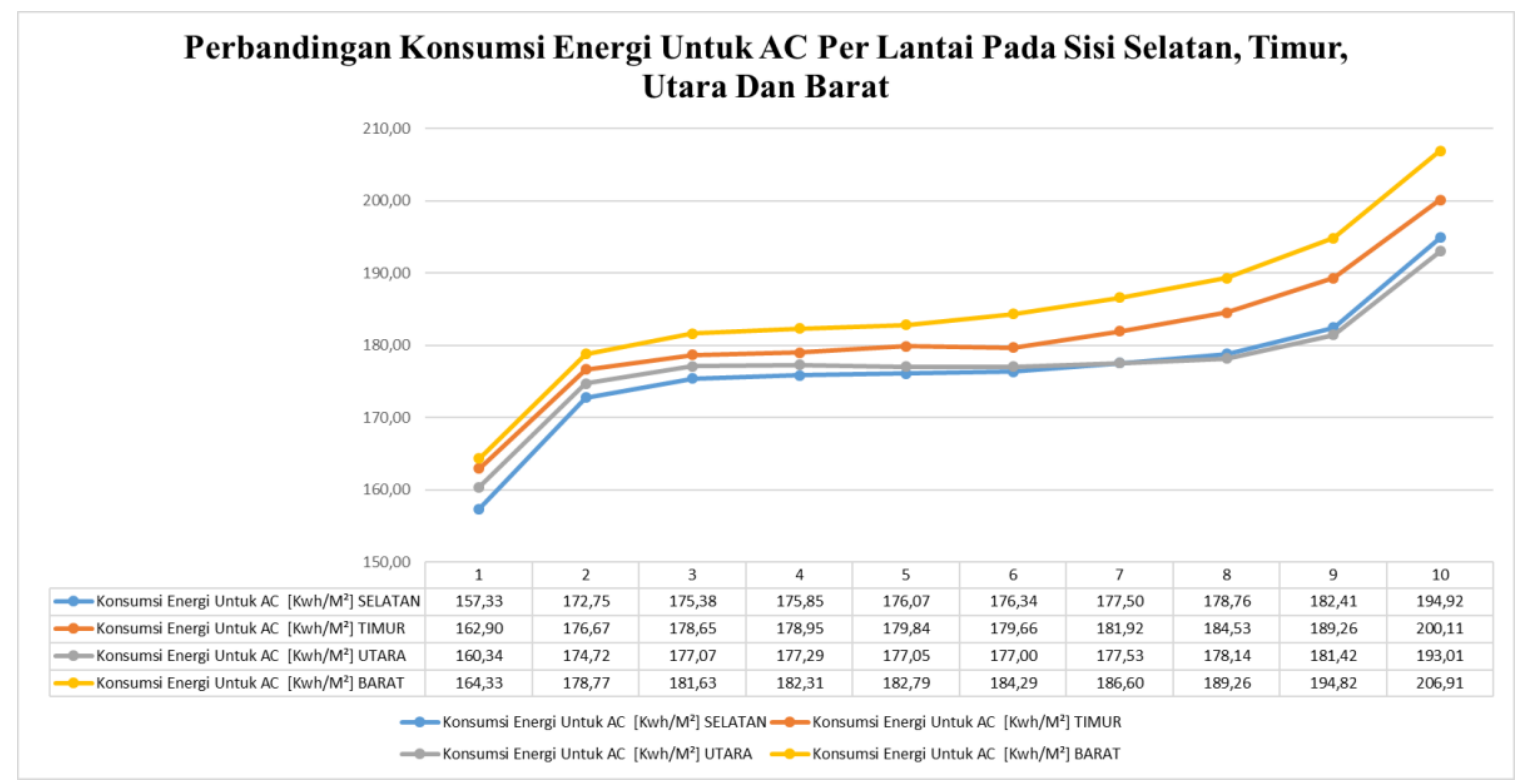

Gambar 12. Perbandingan Konsumsi Pencahayaan per Lantai pada Sisi Selatan, Timur, Utara dan Barat. 
Pada gambar 12 di atas menunjukan bahwa lantai 1 lebih rendah di bandingkan lantai lainya. Pada lantai 1 sampai lantai 10 selalu meningkat konsumsi energi untuk AC.

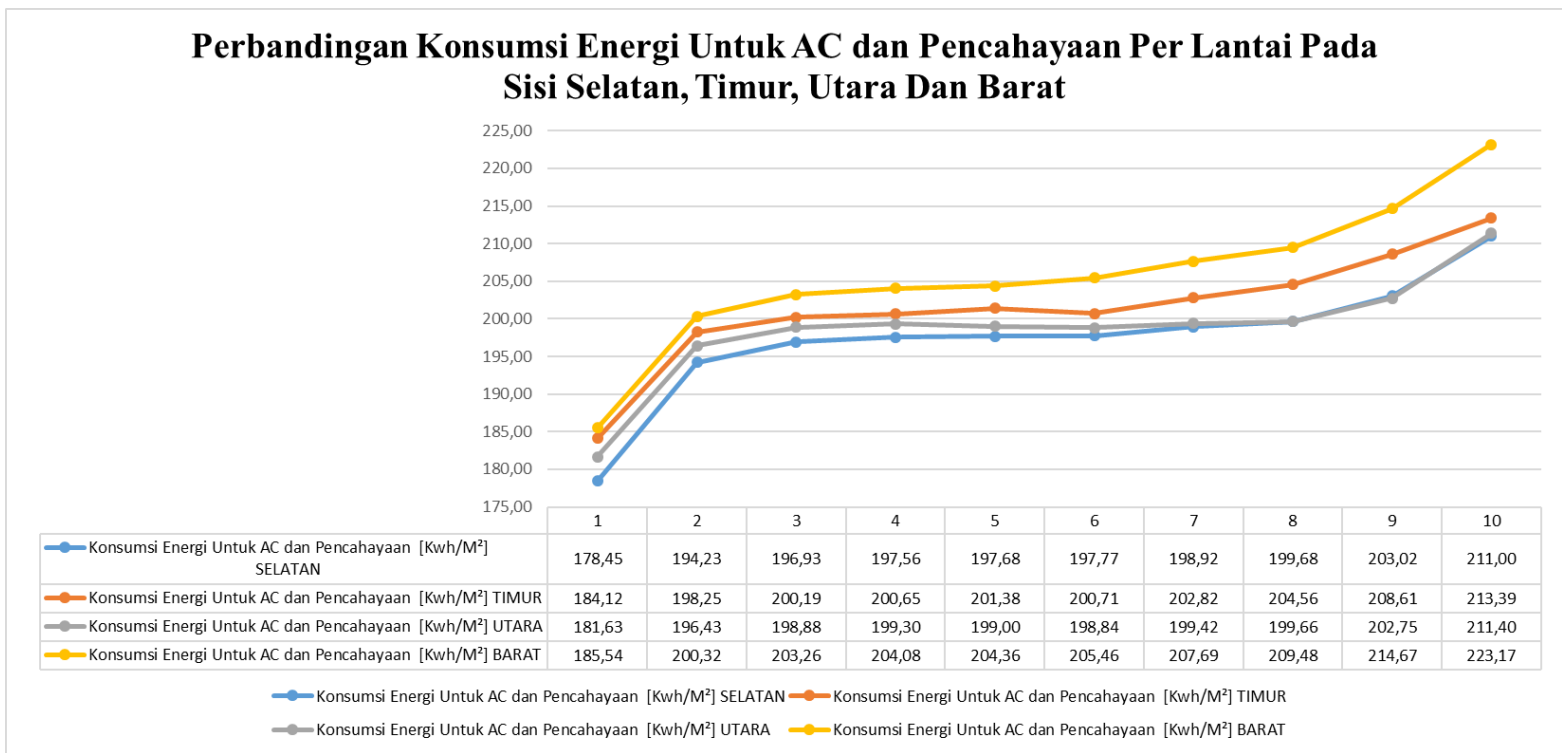

Gambar 13 Perbandingan Total Konsumsi Pencahayaan \& AC per Lantai pada Sisi Selatan, Timur, Utara dan Barat

Pada gambar 13 di atas menunjukan bahwa lantai 1 paling rendah dan lantai 10 paling tinggi di bandingkan lantai lainya dan pada lantai 1 sampai lantai 10 konsumsi total energi untuk $A C$ dan Pencahayaan meningkat.

\section{SIMPULAN}

Menjawab tujuan kajian yaitu mengukur penghematan energi di bangunan tinggi dengan berbagai konfigurasi variabel dimensi courtyard, wwr, jenis kaca terhadap total konsumsi energi untuk ac dan pencahayaan, maka dapat disimpulkan: dari konfigurasi courtyard kombinasi variabel yang paling efektif adalah dimensi courtyard 1, wwr $30 \%$, jenis kaca stopsol; dari variabel dimensi courtyard, wwr dan jenis kaca, untuk total konsumsi energi untuk AC dan pencahayaan yang paling tinggi berpengaruh dalam efesiensi energinya dibandingkan yang lainya adalah jenis kaca clear $15.56 \%$, kaca panashap $9.09 \%$, wwr $70 \% \quad 6,25 \%$, wwr $50 \% 1,91 \%$, dimensi courtyard $20.27 \%$, dimensi courtyard 3 $0.18 \%$; Courtyard berpengaruh terhadap konsumsi energi untuk $A C$, pencahayaan maupun total konsumsi energi untuk $A C$ dan pencahayaan pada ruang $B$; Prosentase perbandingan pencahayaan untuk konfigurasi base case antara ruang $A$ dengan ruang $B$ adalah sisi selatan mengalami perubahan paling tinggi yaitu naik $36.99 \%$ dan sisi barat yaitu naik $59.40 \%$. Pada konsumsi energi untuk AC untuk konfigurasi base case antara ruang $A$ dengan ruang $B$ adalah sisi selatan mengalami perubahan paling rendah yaitu turun $1.94 \%$ pada sisi timur yaitu turun 9.38\%. Sedangkan untuk total konsumsi energi untuk $A C$ dan pencahayaan pada konfigurasi base case antara ruang $A$ dengan ruang $B$ adalah sisi uatara mengalami perubahan paling rendah yaitu 
naik $0.98 \%$ pada sisi timur mengalami perubahan paling tinggi yaitu turun $5.27 \%$; pada pencahayaan ruang $B$ lantai 1 lebih rendah di bandingkan lantai 2 dan lantai 3 . Pada lantai 4 turun lebih rendah dari lantai 3, lantai 5 naik dari lantai 4. Namun, lantai 6 sampai lantai 10 turun. Pada konsumsi energi untuk $A C$ pada lantai 1-10 selalu meningkat. Pada lantai 1 ke lantai 2 mengalami kenaikan sangat drastis. Begitu juga pada lantai 9 menuju ke lantai 10 . Pada total konsumsi energi untuk $A C$ dan pencahayaan sama seperti konsumsi energi untuk AC, lantai 1 paling rendah dan lantai 10 paling tinggi di bandingkan lantai lainya dan pada lantai 1 sampai lantai 10 konsumsi energinya meningkat. Konsumsi energi untuk $A C$ berbanding lurus dengan total konsumsi energi untuk AC dan pencahayaan. Apabila konsumsi energi untuk $A C$ semakin besar, maka konsumsi energi untuk total konsumsi energi untuk AC dan pencahayaan juga semakin tinggi. Sedangkan pencahayaan semakin rendah maka total konsumsi energi untuk $A C$ dan pencahayaan semakin tinggi.

\section{DAFTAR RUJUKAN}

Bekleyen A. dan Dalkiliç N. 2011, The influence of climate and privacy on indigenous courtyard houses in Diyarbakır, Turkey, Scientific
Research and Essays, Vol. 6(4), pp.908-922.

Joko S dan Yudiartono, 2014, Analisis Prakiraan Kebutuhan Energi Nasional Jangka Panjang Di Indonesia, Strategi Penyediaan Listrik Nasional Dalam Rangka Mengantisipasi Pemanfaatan PLTU Batubara Skala Kecil, PLTN, Dan Energi Terbarukan.

Muhammad Rofiqi Athoillah, 2014, Optimasi Penggunaan Pencahayaan Alami Pada Ruang Kerja Dengan Mengatur Perbandingan Luas Jendela. Jurnal Teknik Pomits Vol. 1, No. 1, (2014) 1-6.

Pemerintah Provinsi DKI Jakarta, 2012, Vol1 Selubung Bangunan, Buku Panduan Pengguna Bangunan Gedung Hijau Jakarta.

Prihadi, W. R., \& Pratama, G. N. I. P. Konfigurasi Batang Pada Perancangan Rangka Atap Bambu. INERSIA, 12(2), 173-183.

Sharif Zain dan Surat, 2010, Concurrence of Thermal Comfort of ourtyard Housing and Privacy in the Traditional Arab House in Middle East, Australian Journal of Basic and Applied Sciences, 4(8): 4029-4037. 